\title{
Sharia Banking Profitability and Liquidity towards Economic Growth in Indonesia
}

\author{
Acep R. Jayaprawira ${ }^{1}$, Roikhan Mochamad Aziz ${ }^{2}$, Dita Nur Amanda ${ }^{3}$ \\ acepjayaprawira@yahoo.com ${ }^{1}$,dynivity@gmail.com ${ }^{2}$,ditanuramanda@gmail.com ${ }^{3}$ \\ Universitas Trisakti ${ }^{1,2,3}$
}

\begin{abstract}
The aim of this study is to determine the significance of Islamic Banking's profitability and liquidity with economic growth in Indonesia during the period 20152017. This work is quantitative, analyzing data in the form of numbers (numeric). The sampling technique used in this analysis is purposeful sampling, which is the process of selecting samples on the basis of criteria, meaning sample selection is not random. The system of analysis employed in this study is to use the VECM test. Islamic banking variables used in this study are ROA, Total Assets, NPF, and Total Financing. While the economic growth variable used is GDP. The results of this study indicate that the development of Islamic banking has a relationship with economic growth in Indonesia, which is characterized by a long-term relationship between all variables of Islamic banking to GDP. While in the short term, only the variable ROA, Total Assets, and Total Sharia Banking Financing only affect GDP.
\end{abstract}

Keywords: ROA, Total Assets, NPF, Total Financing, GDP, Islamic Banks.

\section{Pendahuluan}

Pada RAPBN 2017, pemerintah masih memperkirakan adanya inflasi sebesar 4 persen, tingkat pengangguran berada pada kisaran 5,3-5,6 persen, tingkat kemiskinan berada pada kisaran 9,5-10,5 persen, indeks gini rasio sebesar 0,38 persen, dan indeks pembangunan manusia sebesar 75,3. Namun demikian pertumbuhan Indonesia masih dapat dikatakan meningkat, pada grafik 1.1 terlihat bahwa jumlah produk domestik bruto (PDB) yang semakin bertambah setiap triwulannya sehingga pada triwulan ketiga di tahun 2017 mencapai sebesar Rp 2.500 triliun [1].

Indonesia yang semakin meningkat salah satunya dipengaruhi oleh jasa keuangan yang ada di Indonesia. Terlihat bahwa pada tahun 2017 porsi produk domestik bruto (PDB) untuk jasa keuangan dan perbankan didominasi oleh jasa perantara keuangan yang tidak lain adalah perbankan yang pada triwulan ketiga mencapai sebesar Rp 62 triliun. Hubungan antara pengembangan sektor keuangan ditandai dengan peningkatan jumlah produk dan layanan perbankan, dan lembaga perantara lainnya serta transaksi keuangan di pasar saham dan pertumbuhan ekonomi telah lama menjadi subjek penelitian ekonomi. Sektor keuangan memainkan peran penting dalam mendorong beragam sektor ekonomi untuk berkembang. Itu karena lembaga perbankan dapat memanfaatkan surplus modal pihak ketiga untuk diinvestasikan di berbagai sektor ekonomi yang membutuhkan pendanaan. Jika sektor keuangan berkembang dengan baik, akan ada lebih banyak aliran dana yang dapat dialokasikan untuk industri produktif, dan lebih banyak infrastruktur fisik yang dapat dihasilkan yang akan berkontribusi positif terhadap pertumbuhan ekonomi di kemudian hari. 
Pertumbuhan positif dan keberhasilan di sektor keuangan akan dikaitkan secara positif dengan kinerja ekonomi suatu negara. Sektor keuangan dapat menjadi sumber pertumbuhan besar bagi ekonomi riil [2].

Dalam revolusi industri era 4.0, digitalisasi menjadi kekuatan yang signifikan terutama untuk industri perbankan, khususnya perbankan Islam. Padahal, adopsi teknologi dianggap mampu mendorong pertumbuhan dan perkembangan perbankan syariah di Tanah Air yang dinilai masih belum optimal dibandingkan potensinya. [3].

Transisi teknologi akan meningkatkan produksi, meningkatkan kualitas dan produktivitas, yang tentu saja akan membantu keberhasilan dalam profitabilitas. Penggalangan dana oleh bank akan lebih mudah dengan diperkenalkannya teknologi digital. Publik, tentu saja, secara bertahap difasilitasi untuk melakukan layanan transaksi perbankan dan menempatkan dananya dengan mengorbankan hukum syariah.

\section{Metode}

Tujuan dari penelitian ini adalah untuk menguji dampak profitabilitas dan likuiditas perbankan syariah terhadap perkembangan ekonomi Indonesia. Karya ini bersifat kuantitatif, menganalisis data dalam bentuk angka (numerik). Penelitian ini menggunakan data bulanan dari laporan keuangan untuk bank syariah dari 2015 hingga 2017.

Populasi dalam penelitian ini adalah semua bank syariah di Indonesia, baik spin-off maupun yang belum.

Penentuan sampel dalam penelitian ini menggunakan purposive sampling yang artinya pengumpulan sampel dipilih berdasarkan faktor-faktor tertentu dan pengumpulan sampel tidak acak mana informasi yang diperoleh dengan faktor-faktor tertentu. Contohnya adalah bank syariah yang melakukan spin off. Hingga saat ini, Indonesia telah memiliki 13 bank umum syariah.

Sistem pengumpulan data yang digunakan dalam penelitian ini menggunakan proses dokumentasi, yang merupakan sistem yang mengumpulkan informasi dan data dari atau dari lembaga terkait melalui penelitian perpustakaan dan analisis literatur dan laporan keuangan yang disediakan oleh bank syariah yang bersangkutan.

Model penelitian yang dibuat dalam penelitian ini adalah:

Dimana:

$$
\mathrm{PDB}=\alpha 0+\alpha 1 \mathrm{ROA}+\alpha 2 \mathrm{TA}+\alpha 3 \mathrm{NPF}+\alpha 4 \mathrm{TP}+\mathrm{e}
$$

PDB $=$ Produk Domestik Bruto

$\alpha 0, \alpha 1, \alpha 2, \alpha 3, \alpha 4=$ koefisien

ROA $=$ Return On Asset

$\mathrm{TA}=$ Total Aset

NPF $=$ Net Performing Financing

$\mathrm{TP}=$ Total Pembiayaan

$\mathrm{e}=$ error $/$ tingkat kesalahan ++++

Teknik Analisis

1. Uji Akar Unit (Unit Root Test)

2. Uji Kointegrasi Johansen (Johansen Cointegration Test)

3. Uji Kausalitas Granger (Granger Causality) berdasarkan Error Correction Model 


\section{Pembahasan}

Penelitian ini menggunakan analisis uji ekonometrik yang dibagi menjadi dua tahap, yaitu: tahap uji pra-estimasi, dan tahap uji estimasi. Tahap pra-estimasi ini terdiri dari tes untuk stasioneritas data, penentuan lag optimal dan tes untuk kointegrasi. Proses tes estimulasi terdiri dari Granger Causality Test, VECM Test, Impulse Response Function (IRF), dan FEVD Test.

Alat yang digunakan adalah tes augmanated dickey fuller (ADF) dengan poin signifikansi 5 persen. Jika nilai uji statistik ADF lebih rendah dari nilai kritis Mackinnon (nilai kritis) atau jika nilai probabilitas uji statistik ADF lebih rendah dari alpha 0,05 , maka dapat diasumsikan bahwa data yang digunakan tidak memiliki unit root atau stasioner dengan kata lain .

Tabel 1 Hasil Uji Stasioneritas Data Tingkat $1^{\text {st }}$ Difference

\begin{tabular}{|c|c|c|c|}
\hline Variabel & ADF Test & $\begin{array}{c}\text { ADF Mckinnon } \\
\text { Critical Value (5\%) }\end{array}$ & Keterangan \\
\hline ROA & -8.035649 & -2.936942 & Stasioner \\
\hline Total Aset & -8.072019 & -2.936942 & Stasioner \\
\hline NPF & -7.788666 & -2.936942 & Stasioner \\
\hline Total Pembiayaan & -7.038938 & -2.936942 & Stasioner \\
\hline PDB & -5.895057 & -2.936942 & Stasioner \\
\hline
\end{tabular}

Sumber: Hasil Running Eviews 8.0

Pada Tabel 1, dapat ditunjukkan bahwa semua variabel, yaitu Return on Asset (ROA), Total Assets, Net Performing Financing (NPF), Total Financing, dan GDP, stasioner pada Level Diferensial 1 karena nilai Cek ADF lebih rendah selain nilai non-kritis ADF (5 persen) atau nilai kemungkinan lebih rendah dari 5 persen juga dapat ditunjukkan.

Salah satu masalah yang muncul dalam pengujian stasioneritas adalah memutuskan latensi optimal. Jika lag yang digunakan dalam tes stasioner terlalu kecil, maka residu regresi tidak menunjukkan white noise sehingga model tidak dapat memperkirakan kesalahan yang sebenarnya dengan benar [4]. Kami juga memutuskan parameter yang memiliki koreksi kesalahan prediksi akhir (FPE) atau jumlah terkecil dari AIC, SIC, dan HQ di antara berbagai jeda yang diusulkan dalam menentukan jeda optimal.

Tabel 2 Hasil Penentuan Lag Length

\begin{tabular}{|c|c|c|c|c|c|c|}
\hline Lag & LogL & LR & FPE & AIC & SC & HQ \\
\hline 0 & -66.78897 & NA & $3.71 \mathrm{e}-05$ & 3.988276 & 4.208209 & 4.065039 \\
\hline 1 & 59.51019 & 210.4986 & $1.36 \mathrm{e}-07$ & -1.639455 & -0.319856 & -1.178879 \\
\hline 2 & 84.85703 & 35.20394 & $1.45 \mathrm{e}-07$ & -1.658724 & 0.760541 & -0.814335 \\
\hline 3 & 119.2864 & 38.25484 & $1.08 \mathrm{e}-07$ & -2.182577 & 1.336354 & -0.954375 \\
\hline 4 & 147.3939 & 23.42298 & $1.51 \mathrm{e}-07$ & -2.355219 & 2.263378 & -0.743205 \\
\hline 5 & 235.9889 & $49.21941^{*}$ & $1.28 \mathrm{e}-08^{*}$ & $-5.888272 *$ & $-0.170009^{*}$ & $-3.892445^{*}$ \\
\hline
\end{tabular}

Sumber: Hasil Running Eviews 8.0

Dapat dilihat dari tabel 2, bahwa penentuan lag optimal yang disarankan oleh perangkat lunak evaluasi ekonometrik adalah pada lag 5. Perhitungan penundaan optimal kemudian digunakan dalam uji Granger Causality. 
Sebelum memasuki tahap analisis lebih lanjut, penting untuk mengevaluasi hasil estimasi dari metode persamaan VAR yang telah dikembangkan untuk stabilitas melalui pemeriksaan kondisi stabilitas VAR dalam bentuk karakteristik polinomial root pada semua variabel yang digunakan dikalikan dengan jumlah lag setiap VAR. Stabilitas VAR perlu diperiksa karena jika hasil estimasi stabilitas VAR tidak dapat diandalkan maka analisis IRF dan FEVD tidak valid. Sistem VAR dianggap stabil, berdasarkan hasil pengujian, jika semua akar atau akar memiliki modulus lebih besar dari satu. Berdasarkan uji stabilitas VAR yang ditunjukkan pada Tabel 3 dalam laporan ini, dapat disimpulkan bahwa perkiraan stabilitas VAR yang akan digunakan untuk analisis IRF dan FEVD stabil karena rentang modulus $<1$.

Tabel 3 Hasil Uji Stabilitas VAR

\begin{tabular}{|l|l|}
\hline Root & Modulus \\
\hline 1.003595 & 1.003595 \\
\hline 0.836189 & 0.836189 \\
\hline $0.680221-0.270970 \mathrm{i}$ & 0.732206 \\
\hline $0.680221+0.270970 \mathrm{i}$ & 0.732206 \\
\hline $0.612577-0.384929 \mathrm{i}$ & 0.723478 \\
\hline $0.612577+0.384929 \mathrm{i}$ & 0.723478 \\
\hline$-0.443729-0.354242 \mathrm{i}$ & 0.567788 \\
\hline$-0.443729+0.354242 \mathrm{i}$ & 0.567788 \\
\hline$-0.308512-0.042402 \mathrm{i}$ & 0.311412 \\
\hline$-0.308512+0.042402 \mathrm{i}$ & 0.311412 \\
\hline Sumber: Hasil Running Eviews 8.0 &
\end{tabular}

Uji kausalitas Granger digunakan untuk melihat sifat hubungan antara variabel-variabel PDB, pengembalian aset (ROA), total aset, Net Performing Financing (NPF), dan Total Financing.

Berdasarkan temuan dari tabel 4, dapat dilihat bahwa ada hubungan kausal antara variabel produk domestik bruto (PDB) dan total aset variabel perbankan syariah. Ini dapat dilihat dari nilai kemungkinan yang lebih rendah dibandingkan dengan $\alpha=5 \%$. Dapat dilihat bahwa total aset perbankan syariah mempengaruhi produk domestik bruto (PDB) dengan nilai probabilitas $0,0020<0,05$, sedangkan produk domestik bruto (PDB) tidak mempengaruhi total aset perbankan syariah, karena nilai probabilitasnya $0,3637>0,05$. Ini berarti bahwa hanya ada hubungan satu arah antara produk domestik bruto (PDB) dan total aset perbankan syariah.

Tabel 4 Hasil Uji Kausalitas Granger Antara NPF dan ROA

\begin{tabular}{|c|c|c|c|}
\hline Null Hypotesis & Obs & F-Statistic & Prob. \\
\hline PDB does not Granger Cause ROA & 36 & 1.15474 & 0.3637 \\
\cline { 1 - 1 } \cline { 4 - 4 } ROA does not Granger Cause NPF & & 5.04441 & 0.0020 \\
\hline
\end{tabular}

Sumber: Hasil Running Eviews 8.0

Tabel 5 Hasil Uji Kausalitas Granger Antara PDB dan ROA

\begin{tabular}{|c|c|c|c|}
\hline Null Hypotesis & Obs & F-Statistic & Prob. \\
\hline PDB does not Granger Cause ROA & 36 & 2.92304 & 0.0287 \\
\hline ROA does not Granger Cause PDB & & 2.17106 & 0.0835 \\
\hline
\end{tabular}

Sumber: Hasil Running Eviews 8.0

Berdasarkan temuan dari Tabel 5, ada hubungan kausalitas antara variabel Produk Domestik Bruto (PDB) dan variabel Return on Asset Perbankan Syariah (ROA). Ini dapat diilustrasikan dengan melihat nilai kemungkinan lebih rendah relatif terhadap $\alpha=5 \%$. Dapat 
dilihat bahwa Return on Assets (ROA) Perbankan Syariah dipengaruhi oleh Produk Domestik Bruto (PDB) dengan nilai probabilitas $0,0287<0,05$, sedangkan Return on Assets (ROA) Perbankan Syariah tidak mempengaruhi Produk Domestik Bruto (PDB) ) karena nilai probabilitasnya adalah $0,0835>0,05$. Yang berarti hanya ada satu arah hubungan antara Produk Domestik Bruto (PDB) Perbankan Syariah dan Pengembalian Aset (ROA).

Tabel 6 Hasil Uji Kausalitas Granger Antara NPF dan Total Aset

\begin{tabular}{|c|c|c|c|}
\hline Null Hypotesis & Obs & F-Statistic & Prob. \\
\hline NPF does not Granger Cause Total Aset & 36 & 2.80863 & 0.0336 \\
\cline { 1 - 1 } \cline { 4 - 4 } Total Aset does not Granger Cause NPF & & 2.73908 & 0.0371 \\
\hline
\end{tabular}

Sumber: Hasil Running Eviews 8.0

Hal ini dapat ditunjukkan dari tabel 6 di atas bahwa ada hubungan sebab akibat antara variabel Perbankan Syariah Net Performing Financing (NPF) dan variabel Total Perbankan Aset Syariah. Hal ini dapat dilihat dari nilai kemungkinan yang lebih rendah dibandingkan dengan $\alpha=5 \%$. Kita dapat melihat bahwa Net Performing Financing (NPF) Perbankan Syariah berdampak pada Total Aset Perbankan Syariah dengan nilai probabilitas 0,0336 < 0,05, dan juga Total Aset Perbankan Syariah mempengaruhi Net Performing Financing (NPF) Perbankan Syariah dengan nilai probabilitasnya $0,0371<0,05$. Artinya di antara Net Performing Financing (NPF) Perbankan Syariah dengan Total Aset Perbankan Syariah terdapat hubungan dua arah.

Tabel 7 Hasil Uji Kausalitas Granger Antara PDB dan Total Aset

\begin{tabular}{|c|c|c|c|}
\hline Null Hypotesis & Obs & F-Statistic & Prob. \\
\hline PDB does not Granger Cause Total Aset & 36 & 1.15474 & 0.3637 \\
\hline Total Aset does not Granger Cause PDB & & 5.04441 & 0.0020 \\
\hline
\end{tabular}
Sumber: Hasil Running Eviews 8.0

Dapat dilihat dari tabel 7 bahwa ada hubungan kausalitas antara variabel Produk Domestik Bruto (PDB) dan variabel Total Perbankan Syariah. Hal ini dapat dilihat dari nilai kemungkinan yang lebih rendah dibandingkan dengan $\alpha=5 \%$. Total Aset Perbankan Syariah dapat terlihat memengaruhi Produk Domestik Bruto (PDB) dengan nilai probabilitas 0,0020 $<0,05$, sedangkan Produk Domestik Bruto (PDB) tidak berpengaruh terhadap Total Aset Perbankan Syariah karena nilai probabilitasnya 0,3637>0,05. Ini berarti hanya ada satu arah hubungan antara Produk Domestik Bruto (PDB) dan Modal Perbankan Syariah Total.

Tujuan dari uji kointegrasi adalah untuk menentukan apakah variabel-variabel tersebut terkointegrasi secara stasioner. Untuk analisis penelitian kointegrasi ini menggunakan metode Johanes Cointegration Check. Semua variabel stasioner pada titik perbedaan 1 sehingga uji kointegrasi dapat dilakukan melalui Tes Koordinasi Johanes. Jika statistik melacak $>$ nilai kritis maka persamaan tersebut akan diintegrasikan bersama. Oleh karena itu $\mathrm{H} 0=$ nonkointegrasi dengan alternatif $\mathrm{H1}=$ hipotesis kointegrasi. Jika Lacak Statistik> Nilai Kritis, maka tolak $\mathrm{H} 0$ atau terima $\mathrm{H} 1$, yang menunjukkan bahwa ada kointegrasi.

Tabel 8 Hasil Uji Derajat Kointegrasi

\begin{tabular}{|c|c|c|c|c|}
\hline Variabel & Index & Trace Statistic & Critical Value & Keterangan \\
\hline $\begin{array}{c}\text { ROA, Total Aset, NPF, Total } \\
\text { Pembiayaan }\end{array}$ & PDB & 457.3304 & 69.81889 & $\begin{array}{c}\text { Terdapat } \\
\text { Kointegrasi }\end{array}$ \\
\hline
\end{tabular}

Sumber: Hasil Running Eviews 8.0

Jika Lacak Statistik> Nilai Kritis, tolak H0 atau terima H1, yang mengindikasikan kointegrasi (Firdaus, 2011). Hasil tes pada tabel 5 menunjukkan bahwa kointegrasi terjadi 
dengan penggunaan titik signifikansi 5 persen. Ini bisa dilihat ketika Trace Statistics $>$ nilai Critical Value diberikan. Oleh karena itu, ada persamaan kointegrasi, sehingga analisis ini mulai menggunakan VECM untuk melihat dan mengevaluasi hubungan jangka panjang dan jangka pendek antara variabel-variabel tersebut.

Tabel 9 Hasil Uji VECM (Jangka Panjang)

\begin{tabular}{|l|c|c|}
\hline \multicolumn{1}{|c|}{ Variabel } & Koefisien & T-Statistik \\
\hline ROA (-1) & 0.179670 & 6.63389 \\
\hline Total Aset (-1) & -0.039207 & -34.9392 \\
\hline NPF (-1) & 0.018175 & 1.94004 \\
\hline Total Pembiayaan (-1) & -0.034450 & -12.7800 \\
\hline
\end{tabular}

Sumber: Hasil Running Eviews 8.0

ECT adalah residu yang terjadi dalam sistem ECM. Jika koefisien ECT, yaitu koefisien ECT $<1$, adalah penting secara statistik, maka spesifikasi model yang digunakan adalah benar (Safari, 2016). Telah ditemukan dari hasil analisis di atas bahwa ECT $<1$ berjumlah $-0,399353$ dan dapat disimpulkan bahwa temuan dari studi di atas adalah benar.

Dalam jangka pendek, dapat dilihat bahwa hanya variabel return on asset (ROA), total aset dan produk domestik bruto (PDB) itu sendiri yang memiliki dampak besar pada produk domestik bruto (PDB) yang dipertimbangkan dari nilai T-statistik yang lebih besar daripada Ttabel 1,68385.

Seperti dalam jangka pendek, kedua variabel mempengaruhi variabel PDB dalam jangka panjang karena nilai-t lebih besar dari nilai t-tabel 5 persen yaitu 1,68385. Koefisien yang sesuai adalah 0,179670 untuk Return on Asset (ROA), -0,039207 untuk Total Asset, 0,018175 untuk Net Performing Financing (NPF), dan -0,034450 untuk Total Financing.

Berdasarkan temuan VECM ini, variabel pendanaan keseluruhan memiliki hubungan negatif jangka panjang dengan koefisien -0,034450. Besarnya persamaan jangka panjang menunjukkan bahwa setiap kenaikan 1 persen dalam Total Pembiayaan akan disertai dengan penurunan rasio PDB sebesar 0,034450 miliar.

Fungsi Image Impulse Reaction (IRF) akan menampilkan respons variabel karena guncangan variabel lain hingga beberapa periode setelah guncangan. Jika gambar respon impuls menunjukkan bahwa gerakan bergerak lebih dekat ke titik kesetimbangan (konvergensi) atau kembali ke kesetimbangan sebelumnya berarti reaksi kejutan akan hilang sehingga goncangan tidak meninggalkan dampak jangka panjang pada variabel. Gambar 1 adalah hasil dari tes fungsi impuls penelitian (IRF) penelitian ini:

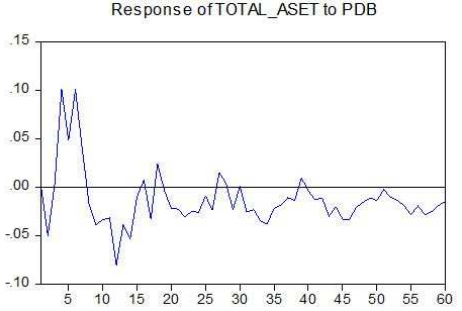

Gambar 1 Hasil IRF Total Aset Perbankan Syariah Terhadap Produk Domestik Bruto (PDB) Sumber: Hasil Running Eviews 8.0

Gambar 1 menggambarkan respon dari total aset perbankan syariah terhadap guncangan (shock) yang terjadi pada produk domestik bruto (PDB) periode 60 bulan atau 5 tahun ke depan. Pada awal periode hingga akhir dapat dilihat bahwa responnya berfluktuatif meskipun 
lebih sering merespon negatif. Hal tersebut menunjukkan bahwa ketika pertumbuhan ekonomi mengalami guncangan, maka akan berdampak juga pada lembaga keuangan termasuk perbankan syariah yang terkadang berdampak positif dan juga negatif. Hal tersebut dikarenakan total aset suatu bank syariah juga dipengaruhi oleh tingkat pendapatan dari nasabah bank syariah tersebut yang juga dihitung ke dalam pendapatan nasional negara Indonesia. Karena pertumbuhan ekonomi yang lebih tinggi suatu negara juga akan membawa peningkatan pendapatan nasional. Dan dengan meningkatnya pendapatan nasional, upah rakyat juga akan meningkat. Dan dengan meningkatnya pendapatan masyarakat, semakin banyak orang di bank syariah yang dapat menabung atau memainkan uang mereka. Karena lebih banyak orang menyimpan uang mereka di bank syariah, aset keseluruhan bank syariah akan naik [4].

Setelah melihat pola dampak guncangan variabel terhadap variabel lain dalam Tes IRF, langkah selanjutnya adalah melakukan tes FEVD atau dekomposisi varian. Uji dekomposisi varians harus memberikan perincian tentang proporsi gerakan dampak guncangan pada suatu variabel terhadap guncangan variabel lainnya di waktu sekarang dan mendatang.

Hasilnya menggambarkan bahwa besarnya komposisi variabel yang mempengaruhi produk domestik bruto (PDB) pada lima tahun ke depan. Dapat dilihat bahwa pada periode pertama Produk Domestik Bruto (PDB) paling besar dipengaruhi oleh total aset sebesar 38 persen sementara pada periode itu shock return on assets (ROA) dan shock Net Performing Financing (NPF) tidak terlihat begitu berpengaruh. Selanjutnya mulai dari periode 1 sampai dengan periode bulan ke 60 proporsi total aset terhadap PDB terlihat semakin besar yaitu terakhir pada periode tahun kelima sebesar 45 persen. Selanjutnya proporsi return on assets (ROA) dari periode awal sampai dengan periode akhir juga semakin bertambah. Sebaliknya proporsi total pembiayaan dan produk domestik bruto (PDB) itu sendiri mengalami penurunan.

\section{Kesimpulan}

Berdasarkan hasil studi kausalitas Granger, ditemukan bahwa tidak ada variabel yang memiliki hubungan kausalitas dua arah dengan variabel produk domestik bruto (PDB) antara total aset, Net Performing Financing (NPF), Total Financing, Return on Aset (ROA) di Perbankan Syariah. Akan tetapi, untuk variabel return on asset (ROA) dan total aset perbankan syariah menunjukkan hubungan kausalitas satu arah terhadap variabel produk domestik bruto (PDB). Dengan demikian total variabel pembiayaan memiliki hubungan kausalitas produk domestik bruto (PDB) satu arah dengan total pembiayaan perbankan syariah.

Berdasarkan hasil uji impulse response function (IRF) ditemukan bahwa respons dari variabel return on asset (ROA), total aset, net performing financing (NPF), dan total pembiayaan perbankan syariah terhadap guncangan (shock) yang terjadi pada variabel produk domestik bruto (PDB) menyebabkan pergerakan return on asset (ROA), total aset, net performing financing (NPF), dan total pembiayaan perbankan syariah menjadi cenderung tidak stabil. Respons pada dua variabel return on asset (ROA) dan total aset memberikan respon positif dan negatif pada produk domestik bruto (PDB). Meskipun masing-masing variabel memberikan respons yang berfluktiatif, secara umum respons keempat variabel tersebut cenderung positif terhadap produk domestik bruto (PDB). Sehingga dapat disimpulkan bahwa respons dari pada variabel total aset, total pembiayaan, return on asset (ROA) perbankan 
syariah masing-masing memiliki pengaruh yang positif terhadap pergerakan produk domestik bruto (PDB).

Berdasarkan temuan studi FEVD, total variabel aset perbankan syariah, yang memiliki komposisi efek terbesar terhadap produk domestik bruto (PDB), dipandang sebagai variabel total aset perbankan syariah. Pada period ke-1pengaruh yang diberikan sebesar 38 persen dan meningkat pada period tahun kelima menjadi hampir 46 persen. Sebelum itu, vektor produk domestik bruto (PDB) itu sendiri, yang 27 persen pada periode pertama dan turun menjadi 13 persen pada periode terakhir, juga memiliki dampak besar.

Studi ini menunjukkan bahwa efek jangka pendek dan jangka panjang dari Return on Asset (ROA), Total Modal, Net Performing Financing (NPF) dan Total Islamic Bank Financing di Indonesia dalam hal ini memiliki dampak langsung pada perkembangan ekonomi. Oleh karena itu, meningkatkan kinerja dalam variabel-variabel ini sangat penting bagi bank syariah untuk menjadi lebih tangguh dalam mencapai pertumbuhan ekonomi yang berkelanjutan. Diperlukan kerjasama yang terintegrasi dan bersinergi dari berbagai pihak yang berkepentingan, yaitu:

1. Pihak regulator menetapkan regulasi yang akan mendukung efisiensi dan pertumbuhan bank syariah, serta menyiapkan infrastruktur pendukung.

2. Meningkatkan kesadaran publik terhadap bank syariah melalui edukasi dan sosialisasi perbankan syariah.

3. Para praktisi perbankan syariah mencari cara untuk menurunkan cost of fund agar bank lebih efisien.

Penelitian ini juga mendukung wacana dan rencana pemerintah untuk memiliki satu bank syariah yang cukup besar untuk menghadapi persaingan yang akan muncul seiring implementasi Indonesia sebagai ekonomi dan keuangan syariah dunia.

\section{References}

[1] Rama, Ali. (2013). Perbankan Syariah Dan Pertumbuhan Ekonomi Indonesia. UIN Syarif Hidayatullah Jakarta. Signifikan Vol. 2 No. 1 April 2013.

[2] Farahani, Yazdan Gudarzi., Sadr, Seyed Mohammad Hossein. (2012). Analysis of Islamic Bank's Financing and Economic Growth: Case Study Iran and Indonesia. Journal of Economic Cooperation and Development, 33, 4 (2012), 1-24.

[3] Abduh, Muhamad., Omar, Mohd Azmi. (2012). "Islamic banking and economic growth: the Indonesian experience. International Islamic Univeristy Malaysia (IIUM)”. International Journal of Islamic and Middle Eastern Finance and Management Vol. 5 No. 1, 2012 pp. 35-47.

[4] Aziz, Roikhan Mochamad. (2008). The Root of Mathematics and Science in Level Compared With Religious Thinking. Proceeding, UIN Jakarta.

[5] Aziz, Roikhan Mochamad. (2015). "Islamic Economics Methodology". Journal of Research Islamic Economics Culture (RIEC) Vol. $1 \mathrm{~Np} .1$. 